\title{
Establishing the Relationship between Trademark Valuation and Firm Performance: Evidence from Iran
}

\author{
Ali Reza Mehrazeen ${ }^{1}$, Omid Froutan ${ }^{1} \&$ Navid Attaran ${ }^{2}$ \\ ${ }^{1}$ Department of Accounting, Neyshabur Branch, Islamic Azad University, Neyshabur, Iran \\ ${ }^{2}$ Faculty of Management, University of Tehran, Tehran, Iran \\ Correspondence: Omid Froutan, Department of Accounting, Neyshabur Branch, Islamic Azad University, \\ Neyshabur, Iran. E-mail: froutan_omid@yahoo.com
}

\author{
Received: April 6, 2012 \\ Accepted: May 2, 2012 \\ Published: June 1, 2012 \\ doi:10.5539/ijef.v4n6p181 \\ URL: http://dx.doi.org/10.5539/ijef.v4n6p181
}

\begin{abstract}
Valuing intangible assets is a critical issue in modern economics; one of the most important ones is trademarks. In a competitive business environment trademarks can protect and create an advantage for firms. In today's complex and ever faster growing market, a suitable trademark affects firm performance and it is considered as a fundamental economic asset for organizations. Valuing intangible assets and determining its relation with performance indicators has two main benefits, first it can be useful for various stakeholders such as stockholders, creditors and employees in assessing firm performance and secondly it can draw standard setter's attention to importance of recognizing and measuring trademarks and other intangible assets in financial statements. The first step in conducting such research is to identify developed and acquired trademarks of listed companies in Tehran Stock Exchange and computing their related value by financial oriented models, then the relationship between trademarks value and accounting performance indicators including net profit (earnings), Return on assets (ROA), Return on Equity (ROE) and Return on sales (ROS) is examined. The results extracted from 2001 to 2011 indicate a significant and direct relationship between mentioned performance indicators and trademarks value.
\end{abstract}

Keywords: trademarks value, ROA, ROE, ROS, financial oriented models

\section{Introduction}

Business firms are seeking to increase their market share and reinforce their competitive advantages by creating an ageless image in their customers mind; thus trademarks are not only a factor influencing market value of the firm but they are also a key variable in reaching aeonic success. Due to low protection for intellectual property in emerging markets, trademarks are crucial in such environments (Chin \& Tsao, 2005). Valuing intangible assets is the most influential way to persuade managers and standard setters that trademarks can be considered as a shared bridge in different and various financial paths of market finders and accountants (Karen \& Gulding, 1999). The value of intangible assets can be expressed in monetary terms so there seems to be a compromise between decision makers, however valuing this asset can be affected by subjective and theoretical factors, anyhow absence of such evaluation cannot extenuate its importance. Clearly unlike stocks and bonds there is no market for rating intangible assets, hence most of the related models are either research or financial based (Kotler \& Pfoertsch, 2006). Registering new trademarks leads to increased sales in forthcoming years (Seethamraju, 2000) and it is expected accounting performance indicators such as earnings, ROA and ROE and ROS react to new developed or acquired trademarks. This research seeks to calculate trademarks value using accounting variables and afterwards determine its interaction with performance indicators.

\section{Literature}

Accounting literature has mainly focused on recognizing and measuring intangible assets however a reliable consensus regarding valuing all the intangible assets is not attained which brings limitations in presenting financial statements. Evidence suggests research and development and promotion expenses along with copyright and trademark possession plays a vital role in valuing and assessing firm performance (Chin \& Tsao, 2005). Aaker (1991) believes trademarks are a strategic vehicle in market mechanism solely due to their ability in creating competitive advantages.

Scrutinizing asset structure of mature and big firms implicates where trademarks proportionate value is higher than other assets, differentiation strategy is mostly chosen by the firm. Assets are important in the eyes of mangers and 
stakeholders simply because they create value, either tangible or intangible (Randle \& Leone, 2009). The logic behind measuring the value of trademarks by financial based models (income orientation) does not rely on historical approach; it rather takes the ability of asset in creating future economical benefit into account. Comparing the measurement approaches regarding tangible and intangible assets brightens the importance of future economical benefits (Kotler \& Pfoertsch, 2006). Proposing a suitable algorithm for rating trademarks in long-term could be an appropriate performance indicator regarding managers (Simon \& Sullivan, 1993), to wit it depicts if managers interests align with investors. Managers can focus on long-term activities which benefit the organization as a whole; consequently this signal affects trademarks value. Barth and Clement (1998) have studied the relations among trademarks value assessed by Financial World magazine, stock prices and returns. This magazine has started trademarks evaluations since 1991 beginning with 41 listed firms, this amount reached 330 in 1996. The results suggest a significant relation between trademarks and owners equity value, they also pointed out trademarks value has straight and positive relation with promotion expenses, operational profit margin and market share of trademarks. Seethamraju (2000) has proposed a model regarding developed or acquired trademarks. He first estimated the value of each trademark and then compared it to Ohlson model valuations (1995); afterwards the relation between market value of equities and their related trademark value was examined. The results demonstrate a significant relation between market values and trademarks. Thus one can claim the necessity for more transparent disclosure of trademarks since it improves financial reporting quality and usage. This research contributes two main benefits to academic literature of intangibles, at first it introduces a new approach in evaluating trademarks valuations and assisting from this phase, the discrepancy between market and book values of intangibles, specifically developed ones, is explained. Kallapur (2004) has assessed the reliability and relevancy of 33 brands asset value recognized by UK firms. They essentially studied the stock price reaction upon a 21 day period after declaration of trademarks value and found a positive and significant relation between stock prices and trademarks value, they also demonstrated a significant relation between market return and brands value in mentioned window. Chin (2005) conducted a research to identify trademarks value in various business cycles. Following Antony and Ramesh (1992) argument, he classified the sample firms into different portfolios of business cycles based on dividend payout ratio, sales growth, capital expenditures and firm age, also Seethamraju's model was used to estimate brands value. They realized as the firm starts fresh and begins to grow and at the end as it reaches slump, the trademarks value decreases uniformly. Ukiwe (2009) has studied the joint effect of brand value and advertising corporate financial performance on stock return; their target was aimed at computer industry, the findings suggest a positive relation between ROA and trademark value. Various researches regarding the role of trademarks in creating value for stockholders have been performed, namely JP Morgan research which indicates that more than one third of firm's value is contributed by trademarks.

Table 1. The role of trademarks in value creation for shareholders

\begin{tabular}{cccc}
\hline Company Name & Brand value to a billion dollars in 2001 & $\begin{array}{c}\text { Value than the market value of } \\
\text { trademarks }\end{array}$ & $\begin{array}{c}\text { Brand value to a billion dollars in } \\
2002\end{array}$ \\
\hline Coca-Cola & 69 & $51 \%$ & 69.6 \\
Microsoft & 95.1 & $21 \%$ & 64.1 \\
IBM & 52.8 & $39 \%$ & 51.2 \\
GE & 42.4 & $14 \%$ & 41.3 \\
Intel & 32.7 & $22 \%$ & 30.9 \\
Nokia & 35 & $51 \%$ & 30 \\
Disney & 32.6 & $68 \%$ & 29.3 \\
McDonald's & 25.3 & $71 \%$ & 26.4 \\
Marlborough & 22.1 & $20 \%$ & 24.2 \\
Mercedes-Benz & 21.7 & $47 \%$ & 21 \\
\hline
\end{tabular}

Table 1 depicts the extent to which trademarks can influence economic performance of firms, for instance $71 \%$ of Macdonald's overall value is created by its brand or Coca Cola which owes $51 \%$ of its value to its well recognized trademark exempting other affiliated brands such as Fanta or Sprite. Nowadays the attention of pioneer firms is shifted towards intangible assets, for example Ford has decreased its tangible assets via investing and acquiring major intangible assets, this company has spent more than 12 billion dollars acquiring Volvo, Jaguar and Land Rover (Lindemann, 2004). The research performed by BBDO consultants (Kotler \& Pfoertsch, 2006) in 2006 investigates the impact of brand on firm performance, examining 23 out of 30 firms listed in DAX, those with strong 
and well known brands were able to overcome the stagnation occurred after 9/11 pretty faster than firms with no or weak trademark.

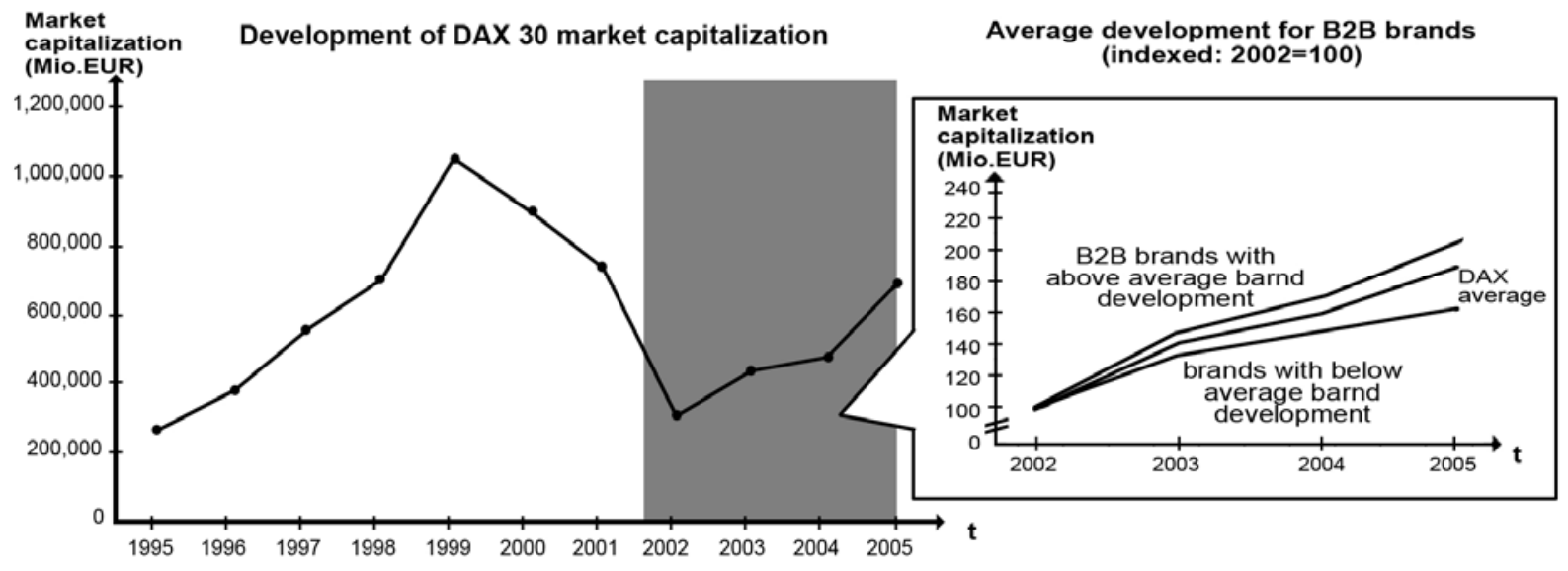

Albeit there is no private or governmental institution in Iran which valuates and assesses the trademarks, except for registering these trademarks solely to protect firms and individuals from copyright abuses, accordingly no astonishing domestic research in this area has been conducted.

\section{Research Hypotheses}

Due to selection of accounting variables in trademark valuation, there are 4 related hypotheses:

$\mathrm{H} 1$ : there is a significant relationship between trademark value and earnings.

$\mathrm{H} 2$ : there is a significant relationship between trademark value and ROA.

$\mathrm{H} 3$ : there is a significant relationship between trademark value and ROE.

H4: there is a significant relationship between trademark value and ROS.

\section{Research Methodology}

Research methodology in this study is inductive in nature. Using cross-correlation and historical information, the relation between trademark value and performance indicators is examined. In order to do so, two groups of models were used, the first group is a financial oriented model based on income which is responsible for trademark valuation and second group establishes the relation between trademark value and performance indicators. Due to constraint in gathering necessary information used in other models, income based models seem more appropriate for developed brands. Seethamraju (2000) has developed a three stage income based model to valuate trademarks which is used in this research.

\subsection{Population and Research Samples}

It is anticipated that trademarks play a more important role in food and beverage industry comparing to chemicals and metals, hence the research population consist of food and beverage firms except sugar production industry listed in Tehran Stock Exchange between 2001 and 2011. One of the basic principles in seethamraju's valuation is related to possession of at least one registered trademark in desired period. With this criterion, the number of eligible firm/years reduced to 60 . The main variable in computing trademark value is the number of registered trademarks in various years. Audited financial statements and their related notes are the main source of data used in this survey.

\subsection{Model Presentation and Variables}

Trademark valuation models are generally subcategorized into two main schools of thought, research oriented and financial based. Research models do not consider the financial value regarding brands per se but they rather take consumer behavioral and attitudinal measures into account, meaning these elements are the ones influencing and creating value for trademarks. On the other hand financial based models use accounting and market variables for trademark valuation (Kotler \& Pfoertsch, 2006), this approach includes 4 schemas which are expense based, market based, formula based and income based (Karen \& Gulding, 1999). Due to limitations in collecting relevant data for desired models it seems appropriate to select income based model for valuing trademarks. Seethamraju's model is 
mainly based on Cobb-Douglas Function, an applied economic function which investigates the relationship between production inputs and outputs. The standard Cobb-Douglas shape is only based on labor and capital for production, however to investigate the relationship between other production inputs and the production volume, logarithm production function of Cobb-Douglas is executed in this research.

First step: seethamraju adjusted Cobb-Douglas function in two ways, trademarks were considered as an effective input affecting sales and promotion expenses were used as a control variable. The first step in valuing trademarks is to assess the relationship between sales and the number of brands. In following model, $\alpha 3$ is the measure showing sales change percentage regarding changes in the number of brands.

$$
\log (\text { SALEt })=\alpha 0+\alpha 1 \log (C t)+\alpha 2 \log (L t)+\alpha 3 \log (T M t)+\alpha 4 \log (A D V t)+\varepsilon t
$$

- $\quad$ Salest: total sales in year $\mathrm{t}$

- $\mathrm{Ct}$ : total fixed assets in year $\mathrm{t}$

- $\quad$ Lt: total labor cost in year $\mathrm{t}$

- TMt: the number of trademarks in year $t$

- ADVt: advertisement expenses in year $t$

- $\quad$ Et: model error

Second step: the amount of sales related to trademarks in desired period is computed using $\alpha 3$. By multiplying this figure by the changes in the number of trademarks, the cash flow resulted from new brands is computed.

$$
\text { IncSALEt }=\left(\alpha 3 \times S A L E_{t}\right) \times P C H T M_{t}
$$

- IncSALEt: representing the amount of sales related to trademark,

- SALEt: the amount of sales,

- PCHTMt: changes in the number of trademarks,

Third step: seethamraju believes cash flows resulting from firm brands are stable in nature, thus by discounting them using Gordon model, trademark value is computed. Weighted average of firms cost of capital in specified period is considered as the discount rate.

$$
T M V_{t}=\left(\operatorname{IncSALE}_{t} \times\left(\text { TmLevel }_{t} / \Delta T M_{t}\right)\right) / W A C C_{t}
$$

- $\quad$ TMVt: trademarks market value,

- IncSALEt: the amount of sales related to trademark,

- TmLevelt: the number of trademarks at the end of period,

- $\Delta \mathrm{TMt}$ : the number of trademarks developed in desired period,

- WACCt: weighted average of cost of capital,

\subsection{Assessing the Relationship between Performance Indicators and Trademarks Value}

To answer research hypotheses, linear regression is executed to investigate the interaction between performance measures and trademarks value. The same model is used to test the four research hypotheses however only dependent variables are changed due to each hypothesis.

$$
\text { Depended variable (Net income, ROA, ROE, ROS) }=\alpha 0+\alpha 1 \text { TradeMark Value }+\varepsilon t
$$

\subsection{Cobb-Douglas Production Function Results regarding Valuing Trademarks}

The coefficient depicting changes in sales regarding the number of trademarks is computed by Cobb-Douglas production function, this coefficient is then used to estimate trademarks value in seethamraju's model. Table 2 shows Fisher test statistic which investigates whether regression model fits the data well, dorbin-watson and kolmogorov-smirnov test results are also demonstrated in this table. The results show that the regression model is appropriate due to significance level and is able to predict $78.1 \%$ of changes in sales. Dorbin-watson statistic is 1.711 which points to lack of solidarity between observations; the p-value related to kolmogorov-smirnov test is $83.3 \%$ which shows the normality of distribution. 
Table 2. Results of Cobb-Douglas model

\begin{tabular}{llllllll}
\hline Model & R & R Square & Adjusted R Square & F & sig & D-W & K-S \\
\hline Cobb-Douglas production function & 0.888 & 0.788 & 0.781 & 113.340 & 0.000 & 1.711 & 0.833
\end{tabular}

Table 3 shows regression estimations, the last column relates to Variance inflation which tests the collinearity of variables.

Table 3. Regression model parameters

\begin{tabular}{|c|c|c|c|c|c|c|c|}
\hline Model & \multicolumn{2}{|c|}{ Unstandardized Coefficients } & \multirow{2}{*}{$\begin{array}{l}\text { Standardized Coefficients } \\
\text { Beta }\end{array}$} & \multirow[t]{2}{*}{$\mathrm{t}$} & \multirow[t]{2}{*}{ Sig } & \multicolumn{2}{|c|}{ Collinearity Statistics } \\
\hline & $\mathrm{B}$ & Std. Error & & & & Tolerance & VIF \\
\hline Constant & 1.639 & 0.194 & & 8.458 & 0.000 & & \\
\hline Fixed assets & 0.538 & 0.045 & 0.639 & 11.895 & 0.000 & 0.603 & 1.658 \\
\hline labor cost & 0.174 & 0.053 & 0.186 & 3.247 & 0.002 & 0.529 & 1.891 \\
\hline trademarks & 0.064 & 0.032 & 0.092 & 2.007 & 0.047 & 0.818 & 1.222 \\
\hline advertisement expenses & 0.093 & 0.025 & 0.183 & 3.758 & 0.000 & 0.736 & 1.358 \\
\hline
\end{tabular}

The final regression model is as follow based on results shown in table 4: (the probability regarding interception is $0.000)$

$$
\log \left(S A L E_{t}\right)=1.639+.538 \log \left(C_{t}\right)+.174 \log \left(L_{t}\right)+.064 \log \left(T M_{t}\right)+.093 \log \left(A D V_{t}\right)+\varepsilon_{t}
$$

The trademark coefficient is 0.064 , meaning one unit increase in the number of trademarks leads to 0.064 unit increases in dependent variable, sales.

\section{Empirical Results}

Table 4 is related to regression model fitness, taking F statistics and significance levels into account, the regression model has a desirable significance level and all the research hypotheses are accepted accordingly.

Table 4. Results of test research hypotheses

\begin{tabular}{lllllllll}
\hline Model & R & R Square & Adjusted R Square & F & Sig & D-W & K-S & Accept or reject the hypothesis \\
\hline H1 & 0.438 & 0.192 & 0.178 & 13.8 & 0.000 & 2.131 & 0.087 & Accept \\
H2 & 0.484 & 0.235 & 0.221 & 17.78 & 0.000 & 2.032 & 0.798 & Accept \\
H3 & 0.304 & 0.093 & 0.077 & 5.99 & 0.018 & 2.176 & 0.268 & Accept \\
H4 & 0.447 & 0.199 & 0.186 & 14.44 & 0.000 & 1.890 & 0.056 & Accept \\
\hline
\end{tabular}

The first hypothesis is accepted with $95 \%$ confidence level, thus there is a significant relationship between earnings and trademarks value. The results for the second hypothesis show $22.1 \%$ coefficient of determination combined with 0.000 significance which leads to rejection of null hypothesis and hence there is significant relationship between trademark value and ROA. Coefficient of determination for the third hypothesis equals to $7.7 \%$ which shows $7.7 \%$ of changes in ROE is explained by trademark value. Regarding fourth hypothesis, the adjusted coefficient of determination is $18.6 \%$ meaning around $19 \%$ of changes of dependent variable (ROS) could be explained by independent variable.

\section{Conclusion}

Intangible assets such as trademarks are considered as one of the fundamental assets of organizations in today's competitive business environment and is it anticipated that they influence firm performance in variety of ways. Valuing trademarks and establishing its relation with performance indicators could be considered as a desirable measure for stakeholders, mean while standard setters could benefit from this while drawing their attention to vital issues such as recognizing and measuring intangibles in financial statements. The main purpose of this study was to assess the relationship between accounting performance indicators and trademarks value. To this end, trademarks were valued using a financial oriented model which is based on income; this train of thought attempts to discount future cash flows resulted from a registered trademark. Afterwards, the relation between accounting performance measures (earnings, ROA, ROS and ROE) and trademark value was investigated by a linear regression model. According to findings in this research, there is a significant relationship between earnings and trademarks value, meaning those firms with higher trademark value were the ones with higher profit. The results show the same 
relation regarding other three performance indicators. These findings indicate the importance of intangible assets which are not usually reported on balance sheet, thus it is expected reporting estimated trademarks value on balance sheet facilitates decision making process by investors and leads to an improved assessment of firm performance.

\section{References}

Aaker, D. A. (1991). Managing Brand Value: Capitalizing on the Value of a Brand Name. The Free Press. New York.

Barth M. E., G Foster, M. Clement, \& R. Kasznik. (1998). Brand Values and Capital Market Valuation. Reveiew of Accounting Studies, 3, 41-68. http://dx.doi.org/10.1023/A:1009620132177

Chin C. L., \& S. M. Tsao. (2005). Trademark Value Accounting Performance: Analysis from Corporate Life Cycle. The Journal of American Academy of Business, 5(1), September, Cambridge.

Kallapur S., \& S. Kwan. (2004). The Value of Brand Assets Recognized by UK Firms. The Accounting Review, 79,151-172. http://dx.doi.org/10.2308/accr.2004.79.1.151

Karen S. C., \& C. Gulding. (1999). Strategic Brand Valuation: A Cross Functional Perspective. Business Horizons, $42(4)$.

Kotler, P. H., \& Pfoertsch, W. (2006). B2B Brand Management. ISBN-10: 3540253602. Springer Publication.

Lindemann, J. (2004). Brand valuation. Interbrand. An Economist book.

Randle D. R, \& R. P. Leone. (2009). Preserving (and growing) brand value in a downturn. Journal of brand Management, 17, 84-89.

Seethamraju C. (2000). The Value Relevance of Trademark. Working paper. New York University, New York, NY.

Simon C. J., \& Sullivan, M. J. (1993). The measurement and determinants of Brand Equity: A Financial Approach. Marketing Science, 12(1), 28-52. http://dx.doi.org/10.1287\%2Fmksc.12.1.28

Ukiwe. \& Alladin. (2009). The Joint Impact of Brand Value and Advertising on Corporate Financial Performance and on stock Rrturn: A Case Study of the Computer Industry. Walden University. 